\title{
Air protection programmes in Poland in the context of the low emission
}

\author{
Janusz Adamczyk $^{1}$ (D) Arkadiusz Piwowar $^{2} \cdot$ Maciej Dzikuć $^{1}$
}

Received: 8 January 2017 / Accepted: 8 May 2017 / Published online: 25 May 2017

(C) The Author(s) 2017. This article is an open access publication

\begin{abstract}
The protection of the air against pollutants from individual boiler plants is a big challenge in Poland. It results mainly from the preference for coal, the national energy carrier, the use of old low-efficiency boilers and the location of Poland in a temperate climate where the heating period lasts at least 5 months. This article presents a wide range of activities aimed at the reduction of the environmental impact of the emissions of pollutants from individual heat sources-the so-called low emission. The article presents the extent of the national legislation resulting from the European Union regulations. It discusses the assumptions of the air protection programmes (APPs) and the low emission reduction programmes (LERPs). The assumptions mentioned above are analysed as part of a life cycle assessment (LCA) analysis and a multi-criterion analysis. An important result of these
\end{abstract}

Highlights

- The atmosphere protection system used in Poland was discussed in the context of the low emission.

- The full scope of legislation related to the subject was presented.

- The air protection programmes used in Poland were discussed.

- Legal, organisational and systemic solutions were proposed for the field.

Responsible editor: Philippe Garrigues

Janusz Adamczyk

J.Adamczyk@wez.uz.zgora.pl

Arkadiusz Piwowar

arkadiusz.piwowar@ue.wroc.pl

Maciej Dzikuć

M.Dzikuc@wez.uz.zgora.pl

1 Faculty of Economics and Management, University of Zielona Góra, ul. Licealna 9, 65-417 Zielona Góra, Poland

2 Faculty of Engineering and Economics, Wrocław University of Economics, Komandorska Street118/120, 53-345 Wrocław, Poland analyses (in the Polish conditions) is the conclusion that a boiler fired with large pieces of wood is an optimal solution from the economic and ecological points of view. The article proposes systemic, organisational and legislative solutions whose implementation could contribute to raising the effectiveness of the protection of the atmosphere.

Keywords "Low emission" · Air protection programmes . LCA analysis · Choice of heat

\section{Introduction}

The combustion of fuels for the purposes of central heating and domestic hot water preparation in buildings causes emissions of gaseous and particulate matter pollutants into the air, considered to be one of the key factors affecting the state of the natural environment (Proszak-Miasik et al. 2013). This negative impact is reduced primarily by optimising the consumption of energy in buildings, for example through the application of thermal insulation in buildings and heat pipes or the replacement of old boilers. The costs of such projects are high and often exceed investors' financing capabilities. This has contributed to the introduction of a number of tools to give preferential financial support to environmental protection projects in Poland, including those in the field of the protection of the atmosphere. The introduction of the instruments for the support of the protection of the atmosphere in Poland has not been historically intended to provide economic support only, but has also been the result of Poland's commitments to improve environmental conditions. Financing environmental activities is intended to accelerate the process of changing and serving as an incentive for investors.

Most of the financial instruments are directed at businesses, local government units and other institutional players. 
Meanwhile, it is a well-known fact that air quality problems are resulted largely from the combustion of fuels for heating purposes in the individual boiler plants installed in residential buildings - the so-called low emission, ${ }^{1}$ which is the main cause of the non-observance of the air quality standards specified by the EU legislation (Directive 2008/50/EC; Directive 2004/107/EC). The low emission problem is exacerbated in Poland by the lack of legal instruments relating to individual buildings, the enforcement of which would make it possible to control the emission levels. Legal instruments are used only in relation to production plants and public buildings. It can be expected that this state of affairs does not motivate residential building owners, managers and tenants to take any actions to minimise their environmental impact. The small number of financial instruments available to individual households in Poland is the cause of the low interest in the activities aimed at the improvement of the energy efficiency. The financing sources for individual households are described in the low emission reduction programmes (LERPs). The LERP will be discussed later in this article.

It should be noted that Poland, Romania and Germany are the EU countries where emissions of benzo(a)pyrene (B(a)P) have increased over the last decade. The overall emission level for this gas in all the EU countries (between 2004 and 2013) remained unchanged (Air quality in Europe 2015; Jakość powietrza w Polsce 2015). In 2013, 87\% of the EU's urban population were exposed to $\mathrm{PM}_{2.5}$ concentrations that exceeded the values established by the $\mathrm{WHO}^{2}$ as the limit levels for the protection of human health. The exposure to ozone in urban areas is still very high. In 2013, 98\% of the EU citizens were exposed to $\mathrm{O}_{3}$ concentrations that exceeded the limits recommended by the WHO (Air quality in Europe 2015). The increased emission of pollutants into the atmosphere in Polish cities does not result only from the combustion of fuels for the production of thermal energy in buildings - other factors include transportation, waste management and manufacturing. However, the low emission (the emission from individual boilers) is one of the major problems affecting the state of the atmosphere in Poland.

The combustion of fuels in the low-power combustion sources causes emissions of substances, such as particulate matter $\left(164,000 \mathrm{Mg}^{3}\right)$, nitrogen oxides $\left(93,000^{3} \mathrm{Mg}\right)$, sulphur

\footnotetext{
${ }^{1}$ Low emission - the emission of products of the combustion of solid, liquid and gaseous fuels into the atmosphere from the emission sources (emitters) located at the altitude not greater than $40 \mathrm{~m}$. A distinction is made between transport emissions, industrial emissions and emissions from the production of heat for central heating and hot water preparation. The combustion products that affect the low emission include the following gases: $\mathrm{CO}_{2}, \mathrm{CO}, \mathrm{SO}_{2}, \mathrm{NO}_{x}$, polycyclic aromatic hydrocarbons, such as benzo(a)pyrene and dioxins, and heavy metals (lead, arsenic, nickel, cadmium) and particulate matter $\mathrm{PM}_{10}$ and $\mathrm{PM}_{2.5}$ (Kaczmarczyk 2015).

${ }^{2}$ World Health Organization

${ }^{3}$ In the case of the so-called low emission sources-i.e. households, services, agriculture and others - the emission values are provided for the year 2013 (GUS 2015).
}

dioxide $\left(284,000^{3} \mathrm{Mg}\right)$, carbon monoxide $\left(1843,000^{3} \mathrm{Mg}\right)$ and heavy metals $\left(1000^{3} \mathrm{Mg}\right)$ (GUS 2015). For comparison, the total emission of the main air pollutants ${ }^{4}$ in the same year (2013) was $407.000 \mathrm{Mg}$ for particulate matter, $799,000 \mathrm{Mg}$ for nitrogen oxides, $847,000 \mathrm{Mg}$ for sulphur dioxide, $2,876,000 \mathrm{Mg}$ for carbon monoxide and $2800 \mathrm{Mg}$ for heavy metals (GUS 2015).

Table 1 presents the percentage share of individual energy carriers used in households for heating in Poland in 2012.

It should be noted that the values presented in the table apply to all households, including single-family and multifamily buildings. Network heat is rarely used in Poland to heat single-family houses, mostly due to the high investment costs (one linear metre of network connection costs around 400 $\mathrm{PLN}^{5}$ ). Therefore, it is mostly people living in multi-family blocks located in cities that have access to the cheaper and more environmentally friendly urban heat, and network heat solutions are rarely used in suburban buildings.

The popularity of using solid fuel boilers in Poland results primarily from the low cost of obtaining heat. Table 2 shows the mean prices of heat produced from different types of fuels in Poland in 2012.

The heating cost for hard coal is one of the lowest among those presented for individual households. The lowest heating cost is that of wood (biomass), but this type of energy carrier is not very popular in Poland, among others due to higher frequencies of boiler operation. The heat obtained from biomass - pellets - is nearly three times as expensive but eliminates the nuisance of having to operate the boiler at more frequent rates. The highest costs are generated by heating with oil and liquid gas. The network heat cost, in turn, is more or less at the average level. The cost of producing heat from sources considered to be more environmentally friendly is high in Poland; this does not apply to burning wood (biomass).

Mostly coal with low heating parameters was used in Poland-imported until 2015 from Russia. However, in 2015 an amendment to the Act of 25 August 2006 on the fuel quality monitoring and control system (Dz. U. of 2015, item 1361) was passed to prevent this from happening. The amendment introduced quality standards for solid fuels - coal and its derivatives. The Customs Service was tasked with ensuring that only coal of a specific quality may enter the Polish market, and the Trade Inspection Agency was made responsible for its trade control (Ustawa z dnia 25 sierpnia 2006).

Another problem that contributes to the increased emissions is the technical condition of boilers, which does not meet

\footnotetext{
${ }^{4}$ The total emission of the main air pollutants encompasses combustion processes in the energy production and transformation sector, non-industrial combustion processes, industrial combustion processes, production processes, fossil fuel mining and distribution, application of solvents and other products, road transportation and waste management.

${ }^{5}$ Currency exchange rate: 1 Euro $\approx 4.20$ PLN.
} 
Table 1 The percentage share of individual energy carriers used in households for heating in Poland in 2012 [\%]

\begin{tabular}{|c|c|c|c|c|c|c|c|c|c|c|}
\hline $\begin{array}{l}\text { Network } \\
\text { heat }\end{array}$ & $\begin{array}{l}\text { Hard } \\
\text { coal }\end{array}$ & $\begin{array}{l}\text { Biomass } \\
\text { (wood) }\end{array}$ & $\begin{array}{l}\text { Methane-rich natural } \\
\text { gas }\end{array}$ & Electricity & Lignite & $\begin{array}{l}\text { Nitrogen-rich natural } \\
\text { gas }\end{array}$ & Coke & $\begin{array}{l}\text { Fuel } \\
\text { oil }\end{array}$ & $\begin{array}{l}\text { Liquid } \\
\text { gas }\end{array}$ & Other \\
\hline 41.54 & 40.84 & 39.98 & 8.83 & 5.35 & 1.36 & 0.94 & 0.74 & 0.45 & 0.32 & 4.45 \\
\hline
\end{tabular}

Source: Energy consumption 2014

the technical requirements. The inspection of the condition of central heating boilers in individual buildings is limited, as well. It is used rarely only for the purposes of the energy certification when a building is being sold or rented. Central heating boilers have relatively low efficiency, which negatively affects the combustion processes and also contributes to the increased emissions. According to the statistical data, the average life of a solid fuel boiler in Poland is 10.3 years (Energy consumption 2014).

The aim of this article is to present the atmosphere protection system in the context of the reduction of the low emission impact in Poland. The article discusses the importance of the air protection programmes (APPs) and the low emission reduction programmes (LERPs) in the context of their importance to the protection of the air. The main methodological assumptions applicable to the above-mentioned programmes were subjected to a life cycle assessment (LCA) analysis, and some legal considerations of the system were presented.

\section{Legal status}

\section{Legal considerations related to the minimisation of the impact of the low emission in Poland}

The Act of 13 April 2012 amending the Environmental Protection Law Act (Dz. U. of 2012, item 460) transposes into the Polish law the provisions of the Directive 2008/50/EC of the European Parliament and of the Council of 21 May 2008 on ambient air quality and cleaner air for Europe (OJ L 152, 11 June 2008, p. 1). Directive 2008/50/EC of the European Parliament and of the Council was established as a result of the implementation of the thematic strategy on air protection, based on "the sixth Community action programme on the environment", whose targets included e.g. the reduction of air pollution down to the levels that minimise their harmful effects on the health of the public and its most vulnerable groups, in particular. The directive specifies the air pollution levels together with the dates of their application and introduces new air quality management mechanisms to be used in zones and agglomerations.

In Poland, there are at least a few legal acts in force that regulate the state of the atmosphere. One of the acts is the above-mentioned Act of 25 August 2006 on the fuel quality monitoring and control system. Article $3 \mathrm{a}$ thereof provides that solid fuels placed on the market shall comply with the quality requirements specified for this type of fuel for the purpose of environmental protection, the impact on human health and the interests of consumers (Ustawa $\mathrm{z}$ dnia 25 sierpnia 2006). The main weakness of this act is that no regulation on the quality requirements for solid fuels has been published yet. Although the act specifies penalties for the trade in low-quality coal, this practice may continue until the guidelines are published under a regulation of the minister responsible for the economy.

The superior act on the environmental management in Poland is the above-mentioned Environmental Protection Law (Dz. U. of 2008, No. 25, item 150, as amended). In accordance with Article 91 thereof, "an air protection programme must be developed for zones ${ }^{6}$ where exceedances of the limit levels or target levels, where applicable plus the margin of tolerance, were found for at least one substance", out of the substances set out in the regulation of the Minister of Environment as of 24 August 2012 on the levels of certain substances in the air (Rozporzadzenie Ministra Środowiska z dnia 24 sierpnia 2012).

The annual air quality assessment is performed for the substances for which the normative values of concentration in the air (limit levels/target levels/long-term objectives) are specified in the national law and EU directives.

The assessment is performed based on the criteria set out for Rozporzadzenie Ministra Środowiska z dnia 24 sierpnia (2012):

- the protection of human health

- the protection of plants

The assessment of the fulfilment of the criteria set out for the protection of human health takes into account 12 substances (Rozporzadzenie Ministra Środowiska z dnia 24 sierpnia 2012):

- $\quad$ sulphur dioxide $\mathrm{SO}_{2}$

- nitrogen dioxide $\mathrm{NO}_{2}$

- carbon monoxide $\mathrm{CO}$

\footnotetext{
${ }^{6}$ The health protection assessment was performed for 46 zones: agglomerations, city zones (above 100,000 residents) and zones (the remaining parts of the provinces). The assessments based on the plant protection criteria were performed only for 16 zones (the assessment excluded agglomerations and city zones) (Rozporzadzenie Ministra Środowiska z dnia 2 sierpnia 2012).
} 
Table 2 Arithmetic mean prices of heat produced from different types of fuels in Poland in 2012 [PLN/GJ]

\begin{tabular}{llllllll}
\hline $\begin{array}{l}\text { Liquid } \\
\text { gas }\end{array}$ & $\begin{array}{l}\text { Fuel } \\
\text { oil }\end{array}$ & $\begin{array}{l}\text { Nitrogen-rich natural } \\
\text { gas }\end{array}$ & $\begin{array}{l}\text { Methane-rich natural } \\
\text { gas }\end{array}$ & $\begin{array}{l}\text { Network } \\
\text { heat }\end{array}$ & $\begin{array}{l}\text { Pellets } \\
\text { (biomass) }\end{array}$ & $\begin{array}{l}\text { Coke Hard } \\
\text { coal }\end{array}$ & $\begin{array}{l}\text { Lignite Wood } \\
\text { (biomass) }\end{array}$ \\
\hline 105.7 & 105.0 & 88.3 & 71.1 & 47.3 & 35.0 & 32.8 & 28.3 \\
\hline
\end{tabular}

Source: Energy consumption 2014

- benzene, $\mathrm{C}_{6} \mathrm{H}_{6}$

- ozone $\mathrm{O}_{3}$

- particulate matter $\mathrm{PM}_{10}$

- lead $\mathrm{Pb}$ in $\mathrm{PM}_{10}$

- arsenic As in $\mathrm{PM}_{10}$

- cadmium $\mathrm{Cd}$ in $\mathrm{PM}_{10}$

- nickel Ni in $\mathrm{PM}_{10}$

- benzo(a)pyrene B(a)P in $\mathrm{PM}_{10}$

- particulate matter $\mathrm{PM}_{2.5}$

The assessments of the fulfilment of the criteria set out for the purpose of protection of plants take into account three substances (Rozporzadzenie Ministra Środowiska z dnia 24 sierpnia 2012):

- sulphur dioxide $\mathrm{SO}_{2}$

- nitrogen oxides $\mathrm{NO}_{x}$

- ozone $\mathrm{O}_{3}$

In addition, Directive 2008/50/EC of the European Parliament and of the Council of 21 May 2008 on ambient air quality and cleaner air for Europe provides that in the event of exceedances of those limit values for which the attainment deadline is already expired, the air quality plans (called programmes in the Environmental Protection Law Act) shall set out appropriate measures, so that the exceedance period can be kept as short as possible (Directive 2008/50/EC).

Air quality assessments in a given zone are made in Poland by the Regional Inspector of Environmental Protection ${ }^{7}$ based on the conducted air quality monitoring. It forms the basis for the classification of zones. ${ }^{8}$ The classification of a zone into class $\mathrm{C}$ means that an air protection programme (APP) needs to be developed. ${ }^{9}$ Tables 3,4 and 5 show zone classes and the required activities depending on the pollutant concentration levels.

\footnotetext{
${ }^{7}$ Environment Protection Inspection - a two-instance institution subordinate to the minister responsible for the issues of the environment, consisting of the Main Inspectorate for the Environmental Protection and 16 provincial inspectorates

${ }^{8}$ The division into zones is made on the basis of the Regulation of the Minister of Environment of 2 August 2012 on the zones where the air quality assessment is performed (Rozporzadzenie Ministra Środowiska z dnia 2 sierpnia 2012).

${ }^{9}$ The inclusion of a zone in class $\mathrm{C}$ or B results from exceedances of a certain criterion value used for substance concentration levels on a specific, usually quite limited, area within the zone and should not be equated with poor air quality throughout the zone.
}

The Regulation on the assessment of the levels of substances in the air specifies the following (Rozporzadzenie Ministra Środowiska z dnia 13 września 2012a):

- the methods and scope of the assessment of substance levels in the air

- the upper and lower assessment thresholds for certain substances in the air and the acceptable frequencies for exceedances of the assessment thresholds

- the scopes of the required measurements, including the division into continuous and periodic measurements

- the criteria for the location of sampling points

- the minimum number of fixed sampling points

- etc.

The subsequent Regulation of the Minister of Environment further specified how to calculate the average exposure indicators and assess the fulfilment of the exposure concentration obligation. This Regulation specifies how to (Rozporzadzenie Ministra Środowiska z dnia 13 września 2010b)

- calculate the average exposure indicator values for a city with a population of more than 100,000 people and agglomerations

- calculate the value of the national average exposure indicator

- assess the fulfilment of the exposure concentration obligation

In accordance with the Regulation of the Minister of Environment of 10 September 2012 on the scope and method of transmission of information on air pollution, for each class $\mathrm{C}$ zone for a specific substance, information is given on exceedances of appropriate criterion values for concentrations of this substance (Rozporzadzenie Ministra Środowiska z dnia 10 września 2012):

- recorded on the basis of the measurements

- determined on the basis of other assessment methods

Exceedances are reported for each substance and position where the critical concentrations were exceeded with the frequency higher than permitted. The list of exceedances should include dates, concentration values and the cause of the exceedance. Similarly, in accordance with the applicable 
Table 3 Zone classes and activities required depending on the pollution levels determined as part of the annual air quality assessment for cases where a limit level is specified and no margin of tolerance ${ }^{\mathrm{a}}$ is specified for the pollutant

\begin{tabular}{lll}
\hline $\begin{array}{l}\text { Class } \\
\text { zone }\end{array}$ & $\begin{array}{l}\text { Pollutant } \\
\text { concentration level }\end{array}$ & Activities required \\
\hline A & $\begin{array}{c}\text { Foes not exceed the } \\
\text { limit level }\end{array}$ & $\begin{array}{l}\text { - Maintain the pollutant concentrations below the limit level and strive to } \\
\text { maintain the best ambient air quality in conformity with sustainable } \\
\text { development. }\end{array}$ \\
C & $\begin{array}{l}\text { Above the limit } \\
\text { level }\end{array}$ & $\begin{array}{l}\text { Specify the areas where limit levels are exceeded. } \\
\text { - Develop or update the air protection programme to achieve appropriate } \\
\text { limit levels for substances in the air. } \\
\text { - Control pollutant concentrations in the areas where limit levels were } \\
\text { exceeded and conduct activities to decrease the concentrations at least to } \\
\text { the limit level values. }\end{array}$
\end{tabular}

${ }^{\text {a }}$ This applies to the following pollutants: sulphur dioxide $\mathrm{SO}_{2}$, nitrogen oxide $\mathrm{NO}_{2}$, carbon oxide $\mathrm{CO}$, benzene $\mathrm{C}_{6} \mathrm{H}_{6}$, particulate matter $\mathrm{PM}_{10}$ and lead $\mathrm{Pb}$ in $\mathrm{PM}_{10}$ - health protection; and sulphur dioxide $\mathrm{SO}_{2}$, nitrogen oxides $\mathrm{NO}_{x}$ - plant protection

${ }^{\mathrm{b}}$ Taking into account the allowable frequencies for exceedances referred to in the regulation of the Minister of Environment on the levels of certain substances in the air regulations, the main and other causes of the exceedance in the zone are determined.

It was assumed that the purpose of the air protection programme is to identify the directions of the corrective actions that will help achieve limit values or target values, specified from the viewpoint of the protection of human health and the environment within zone areas where these values are not met. APP should include a reference to

- the diagnosis of poor air quality on the basis of the analysis of the performed measurements and emission source inventories

- sources of emissions responsible for the air quality in the area of the zone and their percentage shares

- the estimated area where exceedances of the normative concentrations occur

- the number of people exposed to the pollutants

- the corrective actions intended to improve the cleanliness of the air together with the determination of specific objectives, tasks, their estimated costs and sources of financing and expected environmental effects

The national exposure reduction target to be met until 1 January 2020 for the concentration of particulate matter $\mathrm{PM}_{2.5}$ in the air is $18 \mu \mathrm{g} / \mathrm{m}^{3}$ and is specified in another regulation on the national exposure reduction target (Rozporzadzenie Ministra Środowiska $z$ dnia 14 sierpnia 2012).

Another regulation of 11 September 2012 on air protection programmes and short-term action plans (Dz. U. of 2012, item 1028) specifies the following (Rozporzadzenie Ministra Środowiska z dnia 11 września 2012)

- detailed requirements that the air protection programmes and short-term action plans should meet

- the form of preparation and the necessary components of the air protection programmes and short-term action plans

- the scope of issues that should be identified and assessed in the air protection programmes and short-term action plans

Table 4 Zone classes and activities required depending on the pollution levels determined as part of the annual air quality assessment for cases where the limit level and the margin of tolerance are specified for the pollutant

\begin{tabular}{|c|c|c|}
\hline Class zone & Pollutant concentration level & Activities required \\
\hline A & Does not exceed the limit level & $\begin{array}{l}\text { - Maintain the pollutant concentrations below the limit level and } \\
\text { strive to maintain the best ambient air quality in conformity } \\
\text { with sustainable development. }\end{array}$ \\
\hline $\mathrm{B}$ & $\begin{array}{l}\text { Above the limit level but does not exceed } \\
\text { the limit level plus the margins of tolerance }\end{array}$ & $\begin{array}{l}\text { - Specify the areas where the limit level is exceeded. } \\
\text { - Determine the reasons for the exceedance of the limit level for the } \\
\text { substance in the air, and take action to reduce emissions of the substance }\end{array}$ \\
\hline $\mathrm{C}$ & Above the limit value plus the margin of tolerance & $\begin{array}{l}\text { - Determine the areas where the limit value and the limit value plus } \\
\text { the margin of tolerance are exceeded. } \\
\text { - Develop or update the air protection programme aimed at achieving the } \\
\text { limit values for substances in the air. }\end{array}$ \\
\hline
\end{tabular}


Table 5 Zone classes and activities expected depending on the pollutant concentration levels determined as part of the annual air quality assessment for cases where the target value $\mathrm{e}^{\mathrm{a}}$ is specified for the pollutant

\begin{tabular}{|c|c|c|}
\hline $\begin{array}{l}\text { Class } \\
\text { zone }\end{array}$ & $\begin{array}{l}\text { Pollutant } \\
\text { concentration level }\end{array}$ & Activities required \\
\hline A & $\begin{array}{l}\text { Does not exceed the } \\
\text { limit value }\end{array}$ & • None \\
\hline $\mathrm{C}$ & $\begin{array}{l}\text { Above the limit } \\
\text { value }^{\mathrm{b}}\end{array}$ & $\begin{array}{l}\text { - Strive to achieve the target value for the substance within a specified time } \\
\text { using economically reasonable technical and technological measures. } \\
\text { - Develop or update the air protection programme to achieve appropriate } \\
\text { target values for substances in the air. }\end{array}$ \\
\hline
\end{tabular}

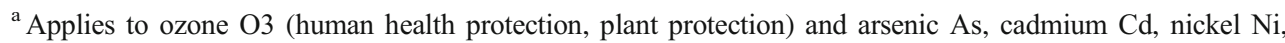
benzo(a)pyrene $\mathrm{B}$ (a) $\mathrm{P}$ in $\mathrm{PM}_{10}$ - human health protection. The target value is also an extra parameter to be taken into account in the annual air quality assessment for particulate matter $\mathrm{PM}_{2.5}$. The limit value is the primary criterion for the assessment of $\mathrm{PM}_{2.5}$

${ }^{\mathrm{b}}$ Taking into account the acceptable frequencies for exceedances specified in the regulation of the Ministry of Environment on the levels of certain substances in the air

\section{The nature of air protection programmes}

The basic problem related to the quality of the air in Poland is the failure to meet the limit on the number of days with exceedances of the maximum daily mean level for particulate matter $\mathrm{PM}_{10}$ and the maximum annual mean level for particulate matter $\mathrm{PM}_{10}$, the maximum annual mean level for particulate matter $\mathrm{PM}_{2.5}$ and the exceedance of the benzo(a)pyrene target value. The low emission originating primarily from the municipal and residential sector, which includes individual sources of heat generation and hot water preparation, as well as small heating plants and transport are responsible for the state of the air quality in Poland.

The first air protection programmes were created in Poland in 2003 and 2004. In the period between 2003 and 2006, 161 zones were qualified to prepare APPs, with the total number of zones in the country being 362 (approx. 100 of them due to an exceedance of the $\mathrm{PM}_{10}$ limit values). In 2006, a new zoning was introduced. Compared to the previous years, their number changed from 362 to 170 and larger areas were created (from 2007, the annual air quality assessments were carried out in accordance with the new zoning). In 2008, 65 zones - that is $38 \%$ of all zones in the country-were qualified to prepare APPs. In 2009, approx. 100 zones were qualified to develop air protection programmes due to exceedances of the limit values for $\mathrm{PM}_{10}$ concentrations and the target values for benzo(a)pyrene. In most cases, target values for benzo(a)pyrene were exceeded in the zones that qualified for the APP due to an exceedance of the $\mathrm{PM}_{10}$ limit values. This does not mean that the air quality situation in Poland has improved, but rather the number of zones has decreased and the surface area of the zones covered by the air protection programmes increased considerably.

In 2010, the number of zones decreased again to 46 (this division is currently in force (Rozporzadzenie Ministra Środowiska z dnia 2 sierpnia 2012)), 45 of which qualified for the preparation of the APP due to exceedances of limit values and target values for particulate matter $\mathrm{PM}_{10}$, particulate matter $\mathrm{PM}_{2.5}$, benzene, benzo(a)pyrene, nitrogen dioxide and arsenic dioxide. Between 2003 and 2010, APPs were developed for all the provinces, mainly as a result of exceedances of the limit values for particulate matter $\mathrm{PM}_{10}$ and benzo(a)pyrene.

The basic conclusions of the air protection programmes are as follows (Schönfelder 2010):

- Most programmes were developed due to exceedance of $\mathrm{PM}_{10}$ limit values and benzo(a)pyrene target values.

- Substances from the emission sources related to the municipal and residential sectors, i.e. the low emission, have the largest share of emissions of all the substances.

- The largest share in emissions is taken by surface sources (approx. $70 \%$ on average), linear sources (13\%) and spot sources $(17 \%)$ within the areas of various zones.

- The largest number of exceedances of the measured substances is recorded in Lesser Poland, Lower Silesian, Silesian and Kuyavian Pomeranian Provinces.

In accordance with the report (Ocena jakości powietrza $w$ strefach $w$ Polsce 2014), exceedances of $\mathrm{PM}_{10}$ limit values were recorded in 36 zones and exceedances of the $\mathrm{PM}_{2.5}$ limit value plus the margin of tolerance were recorded in 24 zones out of the total of 46 zones in the country. In addition, the failure of meeting the limit value for nitrogen dioxide was recorded in 4 zones. At the same time, exceedances of the target values were reported in 42 zones for $\mathrm{B}(\mathrm{a}) \mathrm{P}$, in 4 zones for arsenic and in 6 zones for ozone.

In accordance with the report above, the individual building heating is responsible for the exceedance

- of the limit value for particulate matter $\mathrm{PM}_{10}$ (normative annual mean value $40 \mu \mathrm{g} / \mathrm{m}^{3}$ ) in $88.21 \%$ at the national scale

- of the limit value for particulate matter $\mathrm{PM}_{2.5}$ (normative annual mean value $25 \mu \mathrm{g} / \mathrm{m}^{3}$ ) in $86.5 \%$ at the national scale 
- of the target value for $\mathrm{B}(\mathrm{a}) \mathrm{P}$ (normative annual mean value $1 \mathrm{ng} / \mathrm{m}^{3}$ ) in $98 \%$ at the national scale

Measurements of the $\mathrm{B}(\mathrm{a}) \mathrm{P}$ concentrations in Poland have shown exceedances of normative values for concentrations of this pollutant in a significant number of locations in the country for many years. The exceedances of the target value are associated with a significant increase in the concentrations of $\mathrm{B}(\mathrm{a}) \mathrm{P}$ in the winter (Krajowy program ochrony powietrza 2015).

The atmosphere protection tool in the form of the air protection programme was analysed for technical requirements. The analysis shows that programmes (Krajowy program ochrony powietrza 2015)

- do not contain a well-developed section on corrective actions

- do not include complete calculations of the estimated total cost of the corrective actions

- contain an incomplete diagnosis of the air quality in the indicated area and a non-exhaustive inventory of the emission sources

- indicate only those activities for which it is possible to obtain funding at the municipal level

- do not specify the correct method of monitoring the implementation of the corrective action, e.g. delays occur in the implementation of these actions

- indicate the low emission reduction programmes (LERPs) as major corrective actions despite those programmes having no statutory legal basis

LERPs are a bottom-up initiative based on the air protection programme or the municipal environmental protection programme. LERPs include a system for financing investment costs for the replacement of the heating system specified mostly in the form of a resolution of the city/municipality council (less often in the form of a city mayor order). It may take various organisational forms: from the simplest_-financing occurs on the basis of an invoice through agreements concluded with residents (which limit the possibility of replacing the heating fuel back to solid fuel) - to quite complex programmes. The programmes adopt financing primarily for the purpose of the replacement of the heating system from a solid fuel to gas, oil or electric heating or a connection to the heating network.

\section{Method and results}

\section{Life cycle assessment analysis of the assumptions of the low emission reduction programmes in Poland}

As previously mentioned, the state of atmospheric air in Polish cities is devastating. The city of Kraków ranked the third in the list of the most polluted cities in the European Union in 2013 (European Environment Agency AirBase database 2016). As early as in November 2013, the authorities of Kraków introduced a ban on burning solid fuels in households - primarily coal-which will remain in effect until September 2018 (Adamkiewicz and Huscher 2014). In 2010, the diseases of the respiratory and circulatory systems, which are closely related to air pollution, contributed to the deaths of 507 people out of 100,000 , which equals $52 \%$ of the total number of deaths in Poland (Wojtyniak et al. 2012).

The low emission reduction programmes (LERP) are implementation programmes of the Environmental Protection Programmes, whose adoption belongs to the responsibilities of the municipalities and districts, or the Air Protection Programmes. The LERP programmes present the funding methodology, the substantive part and the general assumptions.

The Environmental Protection Programmes in Municipalities are developed on the basis of

- the Environmental Protection Law

- the Energy Law

- the European Union legislation

It is believed that the implementation of the LERP programmes at the lowest levels of the administrative division $^{10}$ of the country should contribute to the improvement of the atmosphere.

It was assumed that the LERP programmes would be implemented primarily by

1. replacing low-performance and environmentally unfriendly boilers and furnaces with modern heating devices, with a preference for those sources that are more environmentally friendly (gas or fuel oil)

2. using renewable energy sources

3. installation of solar systems for the preparation of hot water and in the case of municipal buildings and public buildings - also thermal modernisation. This step is to be implemented where the old heat source was already replaced with a new higher-performance boiler.

When analysing the first of the LERP assumptions, one can unambiguously accept that it is justified and aims to reduce emissions into the atmosphere by replacing old heat sources with high efficiency ones. Of course, a question can be asked about what difference in performance is needed to justify the replacement of a boiler from the ecological point of view. It can be expected that an ecologically justified necessity to replace a boiler with a higher-efficiency one will also depend on

\footnotetext{
${ }^{10}$ Administrative division of Poland: 1 st degree - 16 provinces, 2 nd degree380 districts, 3rd degree-2479 municipalities
} 
the type of fuel used. Unfortunately, there is no clear answer to these questions in the LERP programme. The programmes only indicate the general parameters available during the sale of boilers and indicate the environmental benefits resulting from a direct comparison of atmospheric emissions between these boilers. They do not take into account the environmental load associated with the need to manufacture the new boiler and later with its utilisation.

The analysis of the second part of the first assumption, meaning the replacement of old boilers with more environmentally friendly ones (gas- or oil-fired boilers) and the use of renewable sources of energy, will be carried out later in this article, taking into account the life cycle assessment (LCA) analysis.

The life cycle assessment (LCA) methodology is a method formulated on the basis of two standards: ISO 14040 and ISO 14044. The LCA analysis consists of four essential stages described in the above-mentioned standards (ISO 14040 2006; ISO 14044 2006):

- goal and scope definition

- LCI-life cycle inventory

- LCIA-life cycle impact assessment

- interpretation

LCA is one of several environmental management techniques that is used among others in the study of environmental aspects throughout the life of the product or process, i.e. "from cradle to grave", which is from extraction of raw materials, through production, distribution, the use phase and reuse or recycling. The LCA technique enables to evaluate the environmental aspects that result from the different life stages of a product. At each stage of product life, as a result of the inventory (LCI), material and energy flows are allocated to individual unit processes restricted by system boundaries. The environmental impact assessment is the result of the evaluation method used (Eco indicator 99 method was applied) and the values of material and energy flows introduced into the computer programme; the above study uses SimaPro computer programme (Sleeswijk 2003; Dylewski and Adamczyk 2011; Dzikuć 2015).

The literature of the subject includes many examples of its application in issues related to the energy or construction industry, e.g. in Dzikuć (2013), Adamczyk and Dzikuć (2014), Lewandowska et al. (2013), Pushkar et al. (2005) and Piwowar et al. (2016).

The environmental impact assessment associated with the change of heat sources for more environmentally friendly ones will be performed using the emission values given in Vieitez and Wolf (2011) and Lachman (2013). The analysis assumes a functional unit equal to $1 \mathrm{kWh}$ of thermal energy production for each heat source. A product system was also adopted - all heat sources are new, and the emission values (Table 6) include the process of the production of thermal energy in the place of its use. The product system does not include the environmental costs associated with the production and recycling of the heat sources (boilers or heat pumps). The emission values are calculated on the basis of primary energy and based on seasonal performance factors. The analysis uses the Eco-indicator 99 assessment method, which is a method commonly used in different sectors of the economy (Dylewski and Adamczyk 2011).

The coal-fired boiler is characterised by the highest environmental impact in terms of carbon dioxide emissions.
Table 6 Values of emissions from different types of heat sources

\begin{tabular}{|c|c|c|c|c|c|}
\hline $\begin{array}{l}\text { Emissions } \rightarrow \\
\text { Heat sources } \downarrow\end{array}$ & $\begin{array}{l}\mathrm{CO}_{2}[\mathrm{~kg} / \\
\mathrm{kWh}]\end{array}$ & $\begin{array}{l}\mathrm{NO}_{x}[\mathrm{mg} / \\
\mathrm{kWh}]\end{array}$ & $\begin{array}{l}\mathrm{CO}[\mathrm{mg} / \\
\mathrm{kWh}]\end{array}$ & $\begin{array}{l}\mathrm{PM}[\mathrm{mg} / \\
\mathrm{kWh}]\end{array}$ & $\begin{array}{l}\text { VOCs [mg/ } \\
\mathrm{kWh}]\end{array}$ \\
\hline Oil-fired boilers & 0.36 & 140 & 50 & 40 & 8 \\
\hline Gas boilers & 0.22 & 80 & 100 & 9 & 15 \\
\hline $\begin{array}{l}\text { Hybrid heat pump combined with a gas } \\
\text { condensing boiler }\end{array}$ & 0.18 & 90 & 0 & 20 & 10 \\
\hline $\begin{array}{l}\text { Heat pumps taking heat from water or } \\
\text { ground }\end{array}$ & 0.12 & 100 & 0 & 25 & 10 \\
\hline Gas absorption heat pumps & 0.15 & 30 & 30 & 5 & 9 \\
\hline Gas (ICE) compressor heat pumps & 0.15 & 95 & 200 & 8 & 12 \\
\hline Coal-fired boiler & 0.61 & 470 & 1150 & 280 & 685 \\
\hline Biomass-fired boiler loaded manually & 0.04 & 80 & 3200 & 140 & 135 \\
\hline $\begin{array}{l}\text { Biomass-fired boiler loaded } \\
\text { automatically }\end{array}$ & 0.03 & 65 & 250 & 70 & 40 \\
\hline Pellet-fired boiler & 0.07 & 240 & 650 & 40 & 6 \\
\hline Boiler fired with large pieces of wood & 0.02 & 340 & 600 & 52 & 22 \\
\hline $\begin{array}{l}\text { Wood burning fireplace (open } \\
\text { combustion chamber) }\end{array}$ & 0.33 & 290 & 1600 & 415 & 30 \\
\hline
\end{tabular}

Source: Vieitez and Wolf 2011; Lachman 2013 
Table 7 The results of the LCA analysis for heat production

\begin{tabular}{ll}
\hline Heat sources $\downarrow$ & Results of the LCA [mPt] \\
\hline Oil-fired boilers & 1.553922 \\
Gas boilers & 0.91819 \\
Hybrid heat pump combined with a gas condensing boiler & 0.776525 \\
Heat pumps taking heat from water or ground & 0.542635 \\
Gas absorption heat pumps & 0.622817 \\
Gas (ICE) compressor heat pumps & 0.632734 \\
Coal-fired boiler & 3.116343 \\
Biomass-fired boiler loaded manually & 0.529055 \\
Biomass-fired boiler loaded automatically & 0.277351 \\
Pellet-fired boiler & 0.384091 \\
Boiler fired with large pieces of wood & 0.205086 \\
Wood burning fireplace (open combustion chamber) & 2.26401 \\
\hline
\end{tabular}

However, despite high harmfulness of this kind of heat source, not all of the emission types analysed are of the highest impact. A wood burning fireplace emits the highest values of particle matter into the atmosphere.

Based on the emission data (Table 6), it is difficult to clearly identify the heat source with the highest environmental impact; therefore, a proposal was made to conduct an LCA analysis based on the Eco-indicator 99 assessment method and a weighing procedure.

The results of the LCA analysis clearly identify the coalfired boiler as the source with the highest environmental impact within the presented product system boundaries $(3.12 \mathrm{mPt})$. Its total environmental impact is twice as high as that of the fuel oil boiler $(1.55 \mathrm{mPt})$ (see Table 7$)$. The woodburning fireplace is also characterised by a high impact on the environment $(2.26 \mathrm{mPt})$. The lowest impact on the environment is that of the boiler fired with large pieces of wood $(0.21 \mathrm{mPt})$.

Therefore, the above-mentioned action associated with the ban on the use of solid fuels for heating purposes in Kraków is completely justified in the light of these results.

In order to determine the optimal solution, a multi-criterion analysis was conducted on selected heat sources. The multicriterion analysis is a set of algorithms used in the selection of the most advantageous solution for e.g. thermal modernisation projects. Each criterion is assigned a weight of 0.5 (the weighting for a particular group in relation to other groups ranges from 0 to 1 ). A weight was adopted that treats either criterion at the same level. The lowest values of the two criteria are considered the optimum solution.

The most economically and ecologically optimal heating solution is wood (the boiler fired with large pieces of wood). The differences in the environmental impact for combustion of biomass (wood) are significant (Tables 7 and 8) and depend on the method in which this process is conducted.
It would be very reasonable to take into account the results of the multi-criterion analysis in the LERPs. It should be noted that due to the variability of the energy carrier prices and the technological advances in the design of new boilers, the values of the multi-criterion analysis are subject to constant change. However, the use of the latest knowledge reduces the possibility of mistakes in programming the low emission reduction system. In the LERP programmes being analysed, potential users are recommended to use such a heat source that makes it impossible to burn municipal waste. Burning waste in boilers is a solution that is often used in households. Heat source efficiency and emissions are obviously taken into account. However, if one takes into consideration the economic analysis, the boiler fired with large pieces of wood proves an optimal solution.

Table 8 Multi-criterion analysis

\begin{tabular}{lll}
\hline Heat source type & $\begin{array}{l}\text { Ecological } \\
\text { criterion } \\
\text { (weight 0.5) }\end{array}$ & $\begin{array}{l}\text { Economic } \\
\text { criterion } \\
\text { (weight 0.5) }\end{array}$ \\
\hline $\begin{array}{l}\text { Oil-fired boilers } \\
\begin{array}{l}\text { Gas-fired boilers } \\
\quad \text { nitrogen-rich natural gas) }\end{array}\end{array}$ & 0.78 & 52.50 \\
$\begin{array}{l}\text { Coal-fired boiler } \\
\text { Biomass-fired boiler loaded } \\
\quad \text { manually }\end{array}$ & 0.46 & 44.15 \\
$\begin{array}{l}\text { Biomass-fired boiler loaded } \\
\text { automatically }\end{array}$ & 0.27 & 14.15 \\
$\begin{array}{l}\text { Pellet-fired boiler } \\
\text { Boiler fired with large pieces of } \\
\quad \text { wood }\end{array}$ & 0.14 & 6.40 \\
$\begin{array}{l}\text { Wood burning fireplace } \\
\quad \text { open combustion chamber) }\end{array}$ & 1.13 & 6.40 \\
\hline
\end{tabular}

Source: own study based on Tables 2 and 7 


\section{Conclusions}

Due to particle matter and benzo(a)pyrene pollution in the air, the Polish economy loses from PLN 40 to 120 billion per year, which includes for example the costs of hospitalisation, lost working days and enterprise losses.

The low emission reduction system in Poland requires legislative changes, as the implementation of the assumptions established in the low emission reduction programmes and the air protection programmes is rather impossible without a support from the state.

\section{A proposal to use legal and economic instruments to reduce low emission in Poland}

Looking for legal solutions conducive to the reduction of the environmental impact of the low emission, a recommendation is made to introduce a tax on pollutants contained in coal, as it is done for individual households in Western European countries. Such a solution would increase the competitiveness of the heat sources with a lower pollutant load emitted into the atmosphere. An alternative to the above-mentioned solution can be changes in tax law pertaining to the periodic reduction of the amount of property tax for the households using an environmentally friendly heat source.

An important element for the improvement of the current low emission reduction system is the introduction of tools of "indirect" stimulation of greener attitudes among owners of residential buildings in the form of preferential loans and/or grants and the use of the funds obtained in this way for a nonrefundable support to owners/administrators of individual residential buildings. Actions of this kind allow to reduce the use of residents' own funds in the investment process, which, in turn, results in the acceleration of the implementation of the projects and achievement of real environmental and energetic benefits.

The low emission reduction programmes assume that as users of the environment, single-family building owners, tenants and managers will be motivated to replace boilers with higherefficiency and/or greener boilers, a result of the application of the appropriate financial instruments (Adamczyk 2014).

As the experiences of different local government units show, the implementation of the low emission reduction programmes contributes significantly to the improvement of the atmosphere. This is achieved mainly by notifying building owners of the financing sources available for thermal modernisation projects. The building owners see economic benefits in these activities, first and foremost. The implementation of the LERP programmes has a significant impact on the change of primary energy carrier for the purpose of heating buildingsfrom a solid fuel (hard coal, often of poor quality) to other greener fuels (natural gas, fuel oil or biomass). The fashion in which these fuels are burned is also important, as was shown in the LCA analysis. In addition, this makes it possible to burn energy carriers in a more efficient manner (through the replacement of low-performance boilers and furnaces with high-efficiency units as well as installation of renewable energy sources). The heating equipment efficiency is of vital importance in the context of the environmental impact. The Commission Regulation (EU) 2015/1188 of 28 April 2015, which takes into account Directive of the European Parliament and of the Council 2009/125/EC of 21 October 2009 laying down general principles for the setting of ecodesign requirements for energy-related products in annex II, lists the minimum efficiency values for heating devices in force in the European Union as of 1 January 2018 (Commission Regulation (EU) 2015/1188). The transposition of these requirements into the published LERP programmes would facilitate the process of making purchase decisions by property owners even now and would improve the state of the atmosphere.

\section{A proposal of system changes affecting the reduction of low emission in Poland}

An important step for the entire low emission reduction system would be to give greater privileges to chimney-sweeps for the control and supervision of installations in order to ensure good health and safety of residents. Of course, this would require amendments to the legislation in force, as well. In Poland, the chimney-sweep is the only legal person to have immediate contact with individual heat sources and would be able to check these sources in addition to performing chimney installation checks. An alternative to this solution could be the establishment of a separate administrative unit for control or assignment of such privileges to an existing unit e.g. the National Sanitary Inspectorate, which works on the municipal level, following a change of law. The chimney-sweep could also be responsible for evaluating the class of heat source efficiency in individual boiler houses. In the case of an irregularity, they would be obliged to inform users about the need to exchange for higher energy efficiency heat sources (especially for fixed boilers). The Czech Republic introduced a ban on the use of low energy efficiency boilers a few years ago.

\section{A proposal for educating the public about the harmful effects of burning waste in boilers}

All these aspects contribute to the reduction of the emissions of substances harmful to the environment. It should be noted that the indirect effects of the implementation of the programmes include forcing behavioural changes among residents. In the winter (heating period), household furnaces are often used to burn some fractions of municipal waste that should be disposed of in an alternative. This results in an emission of the most hazardous compounds - a process that 
is difficult to assess. This behaviour is not controlled effectively in Poland, as there are no organisational units tasked with this duty. According to the authors, the use of educational spots in the media could draw public attention to the threat posed by waste incineration in domestic boilers.

The Polish Energy Policy until 2030 (currently in force) does not include any direct references to "the low emission" as an important risk to the state of the atmosphere (Polityka energetyczna Polski do 2030 roku 2009). This may indicate that the past decade did not pay much attention to the above problem. Currently, work is underway to adopt the new Polish Energy Policy until 2050, which already includes an appropriate provision that gives much importance to this type of pollution source (Projekt Polityki Energetycznej Polski do 2050 roku 2015).

Acknowledgements This study was conducted and financed in the framework of the research project "Economic, ecological and social aspects of low emission limitations in the Middle Odra", granted by the National Science Centre in Poland, program SONATA, grant no. 2015/19/D/HS4/00210.

Open Access This article is distributed under the terms of the Creative Commons Attribution 4.0 International License (http:// creativecommons.org/licenses/by/4.0/), which permits unrestricted use, distribution, and reproduction in any medium, provided you give appropriate credit to the original author(s) and the source, provide a link to the Creative Commons license, and indicate if changes were made.

\section{References}

Adamczyk J (2014) Legal and Financial Instruments to Improve Energy Efficiency in Poland (original: Instrumenty prawne i finansowe stużace poprawie efektywności energetycznej w Polsce). Dist Heat Heat Vent 45(3):88-98

Adamczyk J, Dzikuć M (2014) The analysis of suppositions included in the Polish Energetic Policy using the LCA technique-Poland case study. Renew Sust Energ Rev 39:42-50

Adamkiewicz $Ł$, Huscher J (2014) Spalanie wegla w domowych piecach. Zagrożenia zdrowotne [The combustion of coal in home stoves. Health risks] Health and Environment Alliance (HEAL). Bruksela. http://www.env-health.org/IMG/pdf/spalanie_wegla_w_ domowych_piecach___zagrozenia_zdrowotne_health_and environment_alliance_2014.pdf (on-line version, date of access 30. 01.2016)

Air quality in Europe - 2015 report (2015) European Environment Agency No 5/2015. Publications Office of the European Union, Luxembourg

Commission Regulation (EU) 2015/1188 of 28 April 2015 implementing Directive 2009/125/EC of the European Parliament and of the Council with regard to ecodesign requirements for local space heaters (OJ L 193, 21.7.2015)

DIRECTIVE 2004/107/EC OF THE EUROPEAN PARLIAMENT AND OF THE COUNCIL of 15 December 2004 relating to arsenic. cadmium. mercury. nickel and polycyclic aromatic hydrocarbons in ambient air (OJ L 023 26.1.2005. p. 3)

DIRECTIVE 2008/50/EC OF THE EUROPEAN PARLIAMENT AND OF THE COUNCIL of 21 May 2008 on ambient air quality and cleaner air for Europe. (OJ L 152 11.6.2008. p. 1)
Dylewski R, Adamczyk J (2011) Economic and environmental benefits of thermal insulation of building external walls. Build Environ 46(12):2615-2623. doi:10.1016/j.buildenv.2011.06.023

Dzikuć M (2013) Applying the life cycle assessment method to an analysis of the environmental impact of heat generation. International Journal of Applied Mechanics and Engineering 18(4):1275-1281

Dzikuć M (2015) Environmental management with the use of LCA in the Polish energy system. Management 19(1):89-97. doi:10.1515/ manment-2015-0007

Energy consumption in households in 2012 (2014) Central Statistical Office Warsaw Publication (Polish and English version) available on www.stat.gov.pl and www.mg.gov.pl

European Environment Agency AirBase database (2016) http://www.eea. europa.eu/data-and-maps/data/airbase-the-european- -air-qualitydatabase-8 (on-line version, date of access 30.01.2016)

GUS (2015) Główny Urząd Statystyczny. Central Statistical Office. Ochrona środowiska 2015. Environment 2015. Warszawa. Publication available on website: www.stat.gov.pl

ISO 14040 (2006) Environmental management—-life cycle assessmentprinciples and framework

ISO 14044 (2006) Environmental management—-life cycle assessmentrequirements and guidelines

Jakość powietrza w Polsce w latach 2013-2014 w świetle wyników pomiarów prowadzonych $w$ ramach Państwowego Monitoringu Środowiska [Air quality in Poland in the years 2013-2014 in the light of the results of measurements conducted in the framework of the State Environmental Monitoring] Główny Inspektorat Ochrony Srodowiska. Warszawa 2015

Kaczmarczyk M (2015) NISKA EMISJA - od przyczyn wystepowania do sposobów eliminacji [LOW EMISSIONS - from the causes of the ways of elimination]. Kraków. Geosystem Burek. Kotyza S.C.. p. 144

Krajowy program ochrony powietrza do roku 2020 (z perspektywa do 2030) [The National Programme for air protection to 2020 (with the prospect of 2030)] Ministerstwo Środowiska. Departament Ochrony Powietrza. Warszawa 2015 (on-line version, date of access 10.01.2016)

Lachman P (2013) Porównanie emisji zanieczyszczeń różnych technologii grzewczych wg raportu IPTS dla Komisji Europejskiej [Comparison of emissions of various heating technologies by IPTS report for the European Commission] InstalReporter 2013. No. 01. pp. 29-30 (on-line version, date of access 05.02.2016)

Lewandowska A, Noskowiak A, Pajchrowski G (2013) Comparative life cycle assessment of passive and traditional residential buildings' use with a special focus on energy-related aspects. Energy and Buildings 67:635-646

Ocena jakości powietrza w strefach w Polsce za rok 2013 [Assessment of air quality zones in Poland for 2013] (2014) Zbiorczy raport krajowy $\mathrm{z}$ rocznej oceny jakości powietrza $\mathrm{w}$ strefach wykonywanej przez WIOŚ według zasad określonych w art. 89 ustawy-Prawo ochrony środowiska. Inspekcja Ochrony Środowiska. Warszawa (on-line version, date of access 10.01.2016)

Piwowar A, Dzikuć M, Adamczyk J (2016) Agricultural biogas plants in Poland - selected technological market and environmental aspects. Renew Sust Energy Rev 58:69-74

Polityka energetyczna Polski do 2030 roku (2009) [The Polish Energy Policy until 2030] Ministerstwo Gospodarki, Warszawa

Projekt Polityki energetycznej Polski do 2050 roku (2015) [Draft Polish Energy Policy until 2050] Warszawa

Proszak-Miąsik D, Nowak K, Rabczak S (2013) (in polish) Wykorzystanie energii stonecznej. jako jednego z czynników poprawiajacych jakość powietrza. The solar energy utilization as one of the aspects improving air quality. J Civil Eng Environ Archit XXX(60(3/13)):239-252. doi:10.7862/rb.2013.50

Pushkar S, Becker R, Katz A (2005) A methodology for design of environmentally optimal buildings by variable grouping. Build Environ 40:1126-1139 
Rozporządzenie Ministra Środowiska z dnia 10 września 2012 r. w sprawie zakresu i sposobu przekazywania informacji dotyczacych zanieczyszczenia powietrza [Regulation of the Minister of Environment of 10 September 2012. On the scope and method of transmission of information on air pollution] (Dz. U. z 18 września 2012 r. poz. 1034)

Rozporządzenie Ministra Środowiska z dnia 11 września 2012 r. w sprawie programów ochrony powietrza oraz planów działań krótkoterminowych [Regulation of the Minister of Environment of 11 September 2012. On air protection programs and short-term action plans] (Dz. U. z 2012 r. poz. 1028)

Rozporządzenie Ministra Środowiska z dnia 13 września 2012a r. $w$ sprawie dokonywania oceny poziomów substancji w powietrzu [Regulation of the Minister of Environment of 13 September 2012. On assessment of levels of substances in the air] (Dz. U. z 18 września 2012 r. poz. 1032)

Rozporządzenie Ministra Środowiska z dnia 13 września 2012b r. $w$ sprawie sposobu obliczania wskaźników średniego narażenia oraz sposobu oceny dotrzymania pułapu stężenia ekspozycji (dla pylu PM2.5) [Regulation of the Minister of Environment of 13 September 2012. On the calculation of the indicators of average exposure and the method of assessing compliance with the ceiling concentration exposure (for PM2.5)] (Dz. U. z 18 września 2012 r. poz. 1029)

Rozporządzenie Ministra Środowiska z dnia 14 sierpnia 2012 r. $w$ sprawie krajowego celu redukcji narażenia [Regulation of the Minister of Environment of 14 August 2012. On the national exposure reduction target] (Dz. U. z 2012 r. poz. 1030)

Rozporządzenie Ministra Środowiska z dnia 2 sierpnia 2012 r. $w$ sprawie stref w których dokonuje się oceny jakości powietrza. [Regulation of the Minister of the Environment of 2 August 2012. On the areas in which it operates air quality.] (Dz. U. z 10 sierpnia 2012 poz. 914)

Rozporządzenie Ministra Środowiska z dnia 24 sierpnia 2012 r. $w$ sprawie poziomów niektórych substancji w powietrzu. [Regulation of the Minister of Environment of 24 August 2012. On the levels of certain substances in the air ] (Dz.U. 2012 poz. 1031)

Schönfelder T (ed.) (2010) Analiza możliwości ograniczania niskiej emisji ze szczególnym uwzględnieniem sektora bytowokomunalnego [Analysis of the possibility of reducing low emissions with particular emphasis on municipal-sector existentially] Opole (wersja on-line - data dostępu 10.01.2016)

Sleeswijk AW (2003) General prevention and risk minimization in LCA: a combined approach. Environ Sci \& Pollut Res 10:69. doi:10.1065/ espr2001.09.090

Ustawa z dnia 25 sierpnia $2006 r$. o systemie monitorowania $i$ kontrolowania jakości paliw [The Act of 25 August 2006. Monitoring and control of fuel quality] (Dz. U. z 2015 r. poz. 1361)

Vieitez ER, Wolf O (2011) Development of European Ecolabel and Green Public Procurement Criteria for Hydronic Central Heating Systems. Background Report Including Draft Criteria Proposal Working Document for First Ahwg-Meeting for the Development of Ecological Criteria for Hydronic Central Heating Systems. DG JRC (IPTS) 2011. European Commission (on-line version, date of access 05.02.2016)

Wojtyniak B, Goryński P, Moskalewicz B (ed.) (2012) Sytuacja zdrowotna ludności Polski i jej uwarunkowania. Narodowy Instytut Zdrowia Publicznego - Państwowy Zakład Higieny. Warszawa http://www.pzh.gov.pl/page/fileadmin/user_upload/ statystyka/Raport_stanu_zdrowia_2012.pdf (on-line version, date of access 30.01.2016) 